\title{
Enkele opmerkings oor Johannes Calvyn se stellings oor die capita doctrina necessaria
}

A D Pont

\section{ABSTRACT}

Some remarks on John Calvin's statements on the capita doctrina necessaria

Calvin mentions that there are capita doctrina necessaria in the whole of the church's doctrine. The meaning of the summa religionis is explored in relation to Calvin's concept of the church. It is shown that Calvin sees the church as a pneumatic organism and not, in the first place, as an institute or an organisational unit. This becomes clear when his letter of dedication to the Lutheran pastors in 1556 is also taken in account. Calvin's summa religionis is seen as an argument that needs to be taken in account in contemporary discussions on the doctrinal centre of the church and on church unity.

\section{WOORD VOORAF}

In die eerste plek wil ek graag stel dat dit 'n voorreg is om deel te mag hê aan 'n huldigingsbundel vir kollega Carl Borchardt. Dit is 'n voorreg om hierdie studie op te dra aan 'n kundige, geleerde en innemende kollega wat nou sy verbintenis met die Universiteit neerlê, maar nie sy verbintenis met wetenskaplike bestudering van die verlede van die kerk nie. Daardie studie, as dit eers begin is, het so 'n bekoring dat dit 'n mens nooit weer loslaat nie. Dit veral omdat die stem van die verlede nooit werklik stil word nie en wysheid en insig meedeel vir die wat ore het om te luister. In sy wetenskaplike werk het kollega Borchardt met 'n fyn luistervermoë daarin geslaag om die stem van die verlede hoorbaar te maak, en om so inhoud en rigting te gee aan ons beperkte skepsels se denke oor die ewiglewende God en sy genadige bemoeienis met ons. Daarvoor dank ons ons gewaardeerde kollega en wens hom 'n rustige en vrugbare lewenstyd toe, noudat hy die voltydse dienswerk kan neerlê. 


\section{INLEIDEND}

Die teologiese wetenskap het in die laaste vier-vyf dekades in al sy dissiplines 'n menigvuldigheid van publikasies opgelewer. Dit is byna onoorsienbaar en slegs met tegnologiese hulpmiddels kan tred gehou word, veral as die gepubliseerde werk dwarsoor die wêreld in ag geneem word. Dit bly waar: "daar kom nie 'n einde aan die skryf van baie boeke nie..." (Pred 12:12). Dan kom die vraag soms op: wat is die essensiële in die teologie waarom dit regtig gaan? Daarin kan Johannes Calvyn, soos in baie ander gevalle, koers aan ons denke gee waar hy enkele stellings formuleer oor die capita doctrina, die onveranderlike summa religionis ${ }^{1}$ (Inst 4.1.12). Hier bied Calvyn 'n maatstaf wat na verskillende kante toe in die teologie en in die lewe en werk van die kerk bruikbaar is. Hoewel dit ook waar is dat dit nie 'n maklike of onfeilbare maatstaf is nie. Tog kan dit 'n positiewe rol speel.

\section{DIE NECESSARIA CAPITA DOCTRINA IN DIE INSTITUSIE}

Johannes Calvyn se opmerkings oor "die hoofpunte van die ware leer" kom voor in die Institusie 4.1.12, dit wil sê in die hoofstuk wat handel oor "die ware kerk waarmee ons eensgesindheid moet behou omdat hierdie kerk die moeder van alle godvrugtiges is" 2 . Dit gaan in hierdie hoofstuk om één van die groot vrae van die sestiende eeu. Naas die vraag na die ware, Bybelse leer wat skerp deur Luther aan die orde gestel is, was daar ook die vraag na die ware kerk en waar dié te vinde is. Met die formulering van die capita doctrina wil Calvyn 'n maatstaf na vore bring waarmee, in eerste instansie, die kerk-wees van die kerk gemeet kan word. Dit is dan ook duidelik dat sy formulering van 'n summa religionis ingebed lê in sy verstaan van die kerk, soos hy dit uit die Skrif aflei. Daarom is dit seker nodig om enkele, onvolledige opmerkings te mak oor Calvyn se kerkbegrip.

Teenoor die massiewe, byna ontologiese kerkbegrip van Rome van daardie dae, het Calvyn 'n dinamiese kerkbegrip na vore gebring waar die organisatories-institutêre op die agtergrond was. Spoelstra ${ }^{3}$ wys daarop dat vir Calvyn die essensie van die kerk die eenheid in geloof en nie in organisasie is nie en dat so gesien die geloofsgemeenskap met Christus die oorheersende is en nie juis lidmaatskap van die kerk nie. Die genadegawe van die geloof skenk die eenheid met Christus en die kerk is slegs 'n middel, die "moeder" waar die gelowiges bymekaar gemaak word om die gelowiges te versorg en te voed. Daarom word die kerk sigbaar waar die 
Woord reg of suiwer verkondig word en waar die Heilige Gees deur die verkondigde Woord, werksaam is (vgl IV.1.3). Die aandag is dus nie op die struktuur, die organisasie of die lidmaatskap van die kerk nie, maar op die-geloofseenheid met Christus. So gesien is die kerk 'n pneumatiese organisme en die essensiële is die eenheid in die geloof met Christus en sy liggaam, die gelowiges, waarvan $\mathrm{Hy}$ die enigste hoof is.

Dit is belangrik om daarop te let dat by Calvyn die nota fidelium voorafgaan aan die kenmerke van die kerk. Die kenmerke van die gelowiges, so stel Calvyn dit, is “....almal... wat sowel in geloofsbelydenis, as in lewenswandel en die deelname aan die sakramente bely dat hulle een en dieselfde God en Christus saam met ons bely". Simpson ${ }^{4}$ wys hier ook op Calvyn se Handelinge-kommentaar waar hy "die eenvoudige en opregte waarheid van God" sien as die enigste "heilige eenheidsband" wat die gelowiges aan Christus en daarom aan mekaar verbind.

So is die gelowige gemeenskap, die kerk, verbind aan die apostels en profete en die Christus-belydenis van die kerk van alle tye en plekke. Daarin lê ook die algemeenheid van die kerk want die doctrina en die geloof daarin is "... die heilige band van die broederlike eenheid..."s.

Calvyn lê klem op die suiwerheid van die leer en die belydenis want die belangrike vraag is na die doctrina, die prediking van die Woord waardeur die kerk bestaan ${ }^{6}$. Die geloofsgemeenskap is immers die troue bewaarder van God se waarheid en die waarheid is aan die kerk toevertrou met die opdrag om die verkondiging van die Woord suiwer te hou. Die suiwerheid beteken dat die Woord na die reël van die geloof van die kerk van alle eeue verkondig sal word (Inst 4.1.10). In hierdie omraming kom die saak van die capita doctrina, die onveranderlike summa religionis na vore.

In die Inst 4.1.12 stel Calvyn: “... want al die hoofpunte van die ware leer het nie net een vorm nie. Sekere aspekte daarvan is so noodsaaklik om te ken dat dit vas en ontwyfelbaar by almal moet wees as besondere leerstellings van die godsdiens. Voorbeelde hiervan is dat daar een God is; dat Christus God is en die Seun van God (is), en dat ons saligheid op God se barmhartigheid berus, en derglike dinge". Die toevoeging van die woorde, "en derglike" dui daarop dat Calvyn hiermee nie 'n nuw'e reël vir die geloof wil aandui nie. Sy argument oor die capita doctrina hier is om te sê dat as hierdie minimum teenwoordig is dan is daar geen rede om die gemeenskap van die kerk op te sê of die vrede daar te versteur nie. Wéér word dit duidelik dat dit vir Calvyn gaan om eenheid in die geloof en die capita doctrina dui die inhoud en grense van die geloof en dus ook van die kerk as geloofsgemeenskap. 
Met die formulering van die capita doctrina formuleer Calvyn dieselfde christologiese sentrum wat so nadruklik ook deur Luther geformuleer is in sy poging om die kerk weer op die fondament van die evangelie te vestig. Die kerk groei vanuit hierdie fondament, die regverdiging van die sondaar deur die geloof alleen en nie deur menslike organisasie of voortreflikheid nie ${ }^{7}$. Omdat die kerk die liggaam van Christus is met die opgestane Heer as sy enige hoof, is die kerk eiendom van Christus. Die gelowiges is daarin hoogstens diensknegte van Christus.

Daarmee kan nie betoog word dat die kerk as organisasie verwaarloos moet word nie. Die teendeel word deur Calvyn aangetoon in sy kerkordenende arbeid ${ }^{8}$. Maar dit is ook duidelik dat die geloofsinhoud van die kerk as geloofsgemeenskap, voorafgaan aan en bepalend moet wees vir die kerk as organisatoriese struktuur. Of om dit baie skerp te stel: die belydenis gaan vooraf aan die kerk en bepaal die vorm, inhoud én gerigtheid van die kerk.

\section{DIE CAPITA DOCTRINA IN CALVYN SE BRIEF AAN DIE SAKSIESE PREDIKANTE}

In 1556 publiseer Calvyn 'n tweede verdediging teen Westphal, gerig teen die strydvaardige Lutherse predikant van Hamburg, Joachim Westphal. Calvyn dra hierdie werk op aan die Lutherse predikante, die kollegas van Westphal, om daarmee aan te dui dat hy nie teen die Lutherse leer as sodanig stryd voer nie, maar teen die skerp en vergaande standpunte van Westphal. In die opdrag en begeleidende geskrif stel Calvyn dat daar meer is wat hulle verenig as skei. In dié argument brei hy die capita doctrina weer op ' $n$ bepaalde manier uit as hy sê dat daar eenheid is:

"Oor die een God en die ware en regte manier om Hom te dien, oor die verdorwenheid van die menslike natuur en die saligheid uit genade, oor die manier waarop die geregtigheid verkry word, oor die amp (of dienswerk) en die werk van Christus, oor die boete (of berou) en die gevolge daarvan, oor die geloof wat, terwyl dit berus op die beloftes van die evangelie, aan ons sekerheid van die heil gee, oor die gebed tot God, en oor al die ander hoofpunte word tog orals by ons dieselfde leer verkondig. Ons roep die een God, ons Vader, in vertroue op dieselfde Middelaar, aan, dieselfde Gees wat ons tot kinders van God maak is die waarborg vir ons toekomstige erfenis, deur dieselfde offer het Christus ons almal versoen, op dieselfde geregtigheid wat Hy vir ons verwerf het, vertrou ons almal en ons roem op dieselfde Hoof." 
Terwyl dit so is', verwonder Calvyn hom daaroor dat daar dan verdeeldheid tussen hulle kan wees. Hier spel Calvyn die basiese boustene van die eenheid in die geloof uit en dui weer dat die eenheid in die geloof van die geloofsgemeenskap wat die kerk is, die eenheid is waarom dit gaan.

In hierdie uiteensetting gryp Calvyn feitlik terug na Nicea $(325 \mathrm{nC})$ as hy die leer oor God, oor Christus en sy werk so sentraal plaas. Daarmee verbind hy sy standpunt met die leer- en belydenistradisie van die vroeë kerk. In Inst 4.1 .2 voeg hy die sola gratia van die reformasie daarby. Hier som Calvyn die trinitariese karakter van die heil op en voeg daaraan toe dat dit die geloof is, wat op die beloftes van die evangelie rus, wat die heilsekerheid gee. "As ons trouens nie onder Christus, ons Hoof met al sy ander lede verenig is nie," stel Calvyn, (Inst 4.1.2), "bly daar vir ons geen hoop op 'n toekomstige erfenis oor nie".

Met die formulering blyk dit tog dat daar vir Calvyn 'n sentrum en 'n omtrek is in die leerstukke van die geloof. Hierdie genuanseerde benadering is nie altyd maklik hanteerbaar nie as die argument dat die Christelike geloofsleer 'n organiese geheel is, na vore gebring word. Tog stel Calvyn dit hier met 'n sekere gemaklikheid.

\section{DIE ESSENSIëLE OF DIE SUMMA RELIGIONIS}

Wanneer Calvyn se opmerkings oor die capita doctrina in Inst 4.1.12 nagelees word en dit saamgelees word met sy opmerkings teenoor die Lutherse predikante in 1556, dan is dit duidelik dat vir Calvyn daar 'n besliste sentrum is in die doctrina van die Skrif. Daardie summa religionis is so belangrik dat daaroor geen onwetenheid aanvaar kan word nie en dat daarvan geen afwyking toegelaat kan word nie. Die christologiese middelpunt van die leer en die geloof trek die grens tussen waarheid en nie-meer-waarheid-nie.

Graafland 10 het met 'n interessante historiese argument daarop gewys dat Calvyn met sy opvatting oor die capita doctrina, dit vir die kerk wat in die calvinistiese tradisie leef, nie maklik gemaak het nie. Dit het byvoorbeeld geblyk in die stryd met die Remonstrante ${ }^{11}$ waar die vraag na vore kom of die leer van die regverdiging deur die geloof alleen of die leer van die uitverkiesing die cor ecclesiae is. Saam met die ander voorbeelde wat Graafland aandui, kom die vraag vanself na vore of Calvyn se stellings altyd bruikbaar en sinvol is.

As daar gelet word op Calvyn se capita doctrina dan is dit: die leer oor God, die leer oor die Here Jesus Christus, dit wil sê, die versoening en 
ten derde, die leer oor die genade, die regverdiging èn die uitverkiesing. Dit is terloops nie heeltemal dieselfde as die capita doctrina wat die Heidelbergse Kategismus (VA 1 en 2) aandui nie. Hierdie capita doctrina verteenwoordig, so sien Calvyn dit, ook die essensie van die eenheid van die kerk. Waar dit bestaan, is daar eenheid.

Dieselfde argument word teruggevind in Artikel 27 van die Nederlandse Geloofsbelydenis (NGB) waar gestel word: "Ons glo en bely 'n enige, katolieke of algemene kerk, 'n heilige vergadering van almal wat waarlik in Christus glo, wat almal hulle volle saligheid in Jesus Christus verwag en in sy bloed gewas is, geheilig en verseël deur die Heilige Gees". Hier word die christologiese sentrum van die kerk saamgevat, die betekenis in eerste instansie van die begrip "suiwer" wat met die prediking gekoppel word in die nota ecclesiae. As gelet word op Calvyn se skrywe aan Somerset in $1548^{12}$, kan dit ook meer uitgebreid gestel word.

In die verbygaan kan net daarop gelet word dat in die NGB, anders as by Calvyn, die nota fidelium (art 29) op die nota ecclesiae volg. Dit dui op 'n geleidelike aksentverskuiwing wat veral in die Franse calvinisme na Calvyn, nog verder gaan. Tog word in die NGB, op die voetspoor van Calvyn, die kerk nog steeds verstaan as 'n pneumatiese organisme met 'n organisatories-institusionele kant.

Opmerklik, selfs in die sestiende eeu, is die feit dat die eenheid in die geloof so 'n primaat gehad het dat die organisatoriese eenheid nie as 'n dwingende saak beskou is nie. So het John Knox se Engelstalige gemeente in Genève bestaan sonder dat dit ooit deel was van die Geneefse kerklike struktuur. Dit het seker ook saamgehang met die feit dat die Geneefse kerk 'n volkskerk was. Dieselfde is ook waar van die Nederlandssprekende vlugtelinggemeentes in die Paltz wat in leer, diens en tug dieselfde was as die landskerk, maar nie deel geword het van die organisatories-institutêre sy van die Duitssprekende kerk nie.

\section{SLOTOPMERKINGS}

By die nagaan en oorweging van Calvyn se opmerkings oor die capita doctrina, val dit op dat sy verstaan van die kerk as 'n pneumatiese organisme, as 'n dinamiese lewensgemeenskap met verloop van tyd, ook binne die calvinistiese tradisie, op die agtergrond geraak het. Spoelstra ${ }^{13}$ wys daarop dat ook in Suid-Afrika in die Afrikaanse kerke Calvyn se visie van die kerk verdring is deur 'n visie dat die kerk eerder 'n instituut, 'n organisasie is wat in stand gehou moet word.

Calvyn se aanduiding van 'n summa religionis kan miskien weer die nadenke stimuleer oor die vraag waarom dit regtig gaan in die bestaan en 
lewe van die kerk. Miskien kan, met 'n sprong, gesê word dat die verhaal van Marta en Maria, soos dit in Lukas 10:38-41 voorkom, hier ook ter sprake is. Uiteindelik, te midde van al die doenighede van ons wat mens is en al die boeke wat ons skrywe, in al ons besig-wees in die kerk en die wêreld, gaan dit naamlik om "die een ding wat nodig is", om die Woord, die evangelie te hoor. Calvyn se opmerkings oor 'n summa religionis kan hierin ons denke miskien 'n bietjie orden en rig.

\section{NOTAS:}

1 Joh Calvinus, "Institutio christianae religionis" in: G Baum, E Cunitz, E Reuss (ed), Ioannis Calvini opera quae supersunt omnia, Brunsvigae 1863-1990 (= CO), 4.1.12.

2 H W Simpson (vert), Institusie van die christelike godsdiens deur die skrywer Johannes Calvyn 1559, Potchefstroom 1991, 1265.

3 B Spoelstra, "Calvin's canon law and influence on churches in South Africa", Calvinus reformator, Potchefstroom 1982.

$4 \quad$ Simpson, $a w, 1279$.

5 Calvinus, C O 48, 336.

6 Calvinus, C O 51, 175 en C O 52, 315.

7 P D L Avis, The church in the theology of the reformers, London 1981, 13.

8 A D Pont, Die historiese agtergronde van ons kerklike reg, Pretoria-Kaapstad $1981,2147$.

9 R Schwarz, Calvins Lebenswerk in seinen Briefen III, Neukirchen 1962, 833.

10 C Graafland, Kinderen van een moeder, Kampen 1989, 87-93.

11 Graafland, $a w, 88-89$.

12 Schwarz, $a w, 256$.

13 Spoelstra, $a w, 253-258$. 